\title{
PENGARUH MODEL PEMBELAJARAN GENERATIF TERHADAP KEMAMPUAN BERPIKIR KRITIS FISIKA DITINJAU DARI PENGETAHUAN AWAL PESERTA DIDIK
}

\author{
Hevida Aulia Yatmi*, Wahyudi, Syahrial Ayub \\ Program Studi Pendidikan Fisika, Universitas Mataram \\ Email: hevida.auliay@gmail.com
}

DOI: http://dx.doi.org/10.29303/jpft.v5i2.1327

\begin{abstract}
This research aims to determine: (1) the effect of generative learning models on students' critical thinking abilities in physics; (2) the effect of initial knowledge on students' critical thinking abilities in physics; (3) the interaction between generative learning models with initial knowledge of students' critical thinking physics abilities. This type of research is a quasi-experimental $2 \times 2$ factorial design. The population were all students of class X MIA SMAN 1 Gunungsari in the 2018/2019 school year. The research sample was taken by using purposive sampling technique, so students in class X MIA 3 were selected as the experimental class and students in class X MIA 4 were as the control class. Initial knowledge data were taken using multiple choice tests of 10 questions and critical thinking abilities data using 5 question essay tests. The results of the data were analyzed using two-way analysis of variance with a significance level of 5\%. The results showed that: (1) there was an influence of generative learning models on students' critical thinking abilities in physics; (2) there is an influence of initial instruction on students' critical thinking abilities in physics; (3) there is no interaction effect between the generative learning model and initial knowledge on the students' critical thinking abilities in physics.
\end{abstract}

Keywords: Generative learning model; initial knowledge; critical thinking skills; physics; students

PENDAHULUAN

Pendidikan merupakan suatu hal yang sangat dibutuhkan oleh setiap individu sebagai bekal di masa depan dan menciptakan generasi penerus yang dapat memajukan bangsa. Karakteristik perkembangan pendidikan abad 21 menuntut peserta didik memiliki keterampilan berpikir tingkat tinggi, salah satunya yaitu kemampuan berpikir kritis. Dikutip dari Global Cities Education Network Report (2012), terdapat 5 keterampilan dasar yang harus dimiliki oleh peserta didik pada abad ke-21 yakni, kreativitas serta inovasi, berpikir kritis (critical thinking), pemecahan masalah (problem solving), pengambilan keputusan (decision making) dan metakognisi.

Ilmu Pengetahuan Alam (sains) merupakan salah satu ilmu pendidikan yang berhubungan dengan cara mencari tahu tentang alam secara sistematis, sehingga IPA bukan hanya penguasaan kumpulan pengetahuan yang berupa fakta-fakta, konsep-konsep, atau prinsip-prinsip saja tetapi juga merupakan suatu proses penemuan. Hakikat sains mencakup proses, produk, dan sikap (Hikmawati \& Gunada, 2013). Fisika merupakan bagian dari sains yang memfokuskan kajiannya pada materi, energi dan hubungan antara keduanya (Gunawan et al. 2017).

Fisika yaitu suatu bentuk pembelajaran untuk memahami berbagai macam fenomena dan atau gejala alam yang terjadi pada kehidupan sehari-hari yang bersifat nyata maupun abstrak. Fenomena tersebut menimbulkan permasalahan yang dapat dipecahkan melalui suatu fakta, konsep ataupun persamaan matematis, hal ini diperoleh melalui proses berpikir ilmiah. Dalam proses pembelajaran fisika sebagian besar guru hanya mengajar dengan model pembelajaran yang terbilang sama dan membuat peserta didik bosan. Guru fisika hanya memberikan materi berupa persamaan matematis dan sedikit sekali dalam 
menjelaskan konsep atau teori, sehingga berakibat pada hasil belajar peserta didik.

Berdasarkan hasil observasi awal yang dilakukan oleh peneliti di SMAN 1 Gunungsari, proses pembelajaran yang berlangsung masih berpusat pada guru, sehingga guru mendominasi ruang kelas dan peserta didik hanya mendengarkan informasi yang disampaikan. Permasalahan yang terjadi juga diakibatkan dari pandangan peserta didik yang selalu mengatakan bahwa fisika sukar dipahami dan penuh dengan rumus-rumus yang harus dihafalkan. Hal tersebut membuat peserta didik kurang tertarik untuk mempelajari fisika sehingga menyebabkan peserta didik pasif di dalam proses pembelajaran dan akibatnya terjadi penurunan proses kegiatan dan atau aktivitas berpikir peserta didik, terutama dalam kemampuan berpikir tingkat tinggi, seperti kemampuan berpikir kritis.

Kemampuan berpikir kritis adalah sebuah proses yang terarah dan jelas yang digunakan dalam kegiatan mental seperti memecahkan masalah, mengambil keputusan, membujuk, menganalisis asumsi, dan melakukan penelitian ilmiah (Johnson, 2008). Kemampuan berpikir kritis memberikan dorongan peserta didik untuk bertindak peka terhadap permasalahan yang di hadapi. Pentingnya kemampuan berpikir kritis tertuang dalam Permendiknas No.23 tahun 2006 tentang Standar Kompetensi Lulusan (SKL) untuk satuan pendidikan Dasar dan Menengah yang menyebutkan bahwa salah satu tujuan satuan pendidikan adalah membangun dan menerapkan informasi dan pengetahuan secara logis, kritis, kreatif dan inovatif (BSNP, 2006).

Tujuan pendidikan untuk membangun kemampuan berpikir kritis belum terlaksana secara utuh, dikarenakan keberhasilan proses pembelajaran juga dipengaruhi oleh peserta didik. Faktorfaktor yang dapat mempengaruhi proses pembelajaran meliputi aspek latar belakang dan sifat yang dimiliki oleh peserta didik. Sifat yang dimiliki meliputi kemampuan dasar, pengetahuan dan sikap. Faktor yang mempengaruhi adalah apa yang diketahui oleh peserta didik, seperti pengetahuan awal. Pengetahuan awal dalam proses pembelajaran akan memudahkan untuk memahami konsep (Adodo, 2013). Apabila peserta didik dapat memahami konsep dengan baik maka akan merangsang keaktifan serta kemampuan berpikir kritisnya. Salah satu model yang ditawarkan peneliti agar dapat digunakan untuk meningkatkan kemampuan berpikir kritis yang ditinjau dari pengetahuan awal yaitu model pembelajaran generatif.

Wena (2016) mengatakan bahwa model pembelajaran generatif pertama kali diperkenalkan oleh Osborne \& Cosgrove. Model pembelajaran generatif menekankan untuk membangun pengetahuan yang sudah dimiliki oleh peserta didik yang nantinya akan dihubungkan dengan pengetahuan yang sudah ada. Sugiana et. al. (2016) menyatakan bahwa model pembelajaran generatif merupakan model pembelajaran yang membimbing peserta didik dalam mengeksplorasi pengetahuan peserta didik untuk memperoleh pengetahuan baru.

Wena (2016) membagi model pembelajaran generatif menjadi empat tahap, yaitu (a) pendahuluan atau disebut tahap ekplorasi, (b) pemfokusan, (c) tantangan atau tahap pengenalan konsep, (d) penerapan konsep. Putri et. al. (2014) menyatakan bahwa pada proses tahapan model pembelajaran generatif ini dapat dilakukan peserta didik secara berkelompok yang terdiri atas 4 sampai 6 orang.

$$
\text { Keunggulan dari model }
$$
pembelajaran generatif menurut Shoimin (2014) yaitu, (a) memberikan kesempatan kepada peserta didik untuk mengungkapkan pikiran, pendapat, dan pemahamannya terhadap konsep, (b) melatih peserta didik untuk mengkomunikasikan konsep, (c) 
melatih peserta didik untuk menghargai gagasan orang lain, (d) memberikan kesempatan kepada peserta didik untuk peduli terhadap konsepsi awalnya (terutama peserta didik yang miskonsepsi). Peserta didik diharapkan menyadari miskonsepsi yang terjadi dan bersedia memperbaikinya, (e) memberikan kesempatan kepada peserta didik untuk mengonstruksi pengetahuannya sendiri (f) menciptakan suasana kelas yang aktif karena peserta didik dapat membandingkan gagasannya dengan gagasan peserta didik lainnya serta intervensi guru, (g) guru mengajar menjadi kreatif dalam mengarahkan peserta didiknya untuk mengkonstruksi konsep yang akan dipelajari, (h) guru menjadi terampil dalam memahami pandangan peserta didik dan mengorganisasi pembelajaran.

Model pembelajaran generatif sangat erat kaitannya dengan pengetahuan awal yang dimiliki oleh peserta didik.Adanya model pembelajaran generatif yang ditinjau dari pengetahuan awal akan menjadi satu kesatuan yang saling melengkapi. Harapan peneliti agar penggunaan model pembelajaran generatif dan pengetahuan awal dapat membentuk maupun meningkatkan kemampuan berpikir kritis fisika peserta didik.

\section{METODE PENELITIAN}

Penelitian ini termasuk penelitian quasi experimental dengan desain factorial design $2 \times 2$. Populasi penelitian ini adalah seluruh peserta didik kelas X MIA SMAN 1 Gunungsari dengan teknik pengambilan sampel menggunakan purposive sampling, sehingga diperoleh X MIA 3 yang berjumlah 24 peserta didik sebagai kelas eksperimen dan X MIA 4 yang berjumlah 25 peserta didik sebagai kelas kontrol.

Variabel dalam penelitian ini terdiri

dari variabel bebas yaitu model pembelajaran generatif yang diberikan pada kelas eksperimen dan pembelajaran konvensional diberikan pada kelas kontrol, variabel terikat yaitu kemampuan berpikir kritis, variabel moderator yaitu pengetahuan awal, dan variabel kontrol yaitu materi ajar, tujuan pembelajaran, instrumen yang digunakan, alokasi waktu, guru yang mengajar, dan cara penilaiannya sama untuk kelas eksperimen dan kelas kontrol. Instrumen yang digunakan adalah tes pengetahuan awal sebagai variabel moderator yang diberikan pada kelas eksperimen dan kelas kontrol sebelum diberikan perlakuan dengan teknik pengumpulan data berupa tes tertulis berbentuk soal pilihan ganda berjumlah 10 soal dan tes kemampuan berpikir kritis yang diberikan pada kedua kelas setelah diberikan perlakuan dengan teknik pengumpulan data berupa soal uraian yang berjumlah 5 soal. Indikator kemampuan berpikir kritis yang digunakan dalam tes kemampuan berpikir kritis ini terdiri dari lima indikator yaitu sebagai berikut: memberikan penjelasan sederhana, membangun keterampilan dasar, menyimpulkan, memberikan penjelasan lebih lanjut, serta mengatur strategi dan taktik (Ennis, 2011).

Instrumen tes yang digunakan peneliti ada dua yaitu tes pengetahuan awal berfungsi untuk menggolongkan peserta didik yang memiliki pengetahuan awal tinggi dan peserta didik yang memiliki pengetahuan awal rendah dengan menggunakan rumus $\mathrm{Z}_{\text {score }}$ dan tes kemampuan berpikir kritisdigunakan untuk mengetahui kemampuan berpikir kritis peserta didik. Instrumen tes tersebut sebelum digunakan dalam penelitian harus memenuhi beberapa syarat yaitu uji validitas, reliabilitas, tingkat kesukaran, dan daya pembeda soal.

Uji hipotesis diawali dengan uji normalitas dan uji homogenitas yang digunakan untuk mengetahui hasil data tes kemampuan berpikir kritis homogen dan terdistribusi normal. Selanjutnya dilakukan 
uji analisis data menggunakan uji analisis statistik parametrik yaitu analisis varian (ANAVA) dua jalan dengan taraf signifikan 5\%. Analisis data dibantu dengan program aplikasi Microsoft Office Excel dan SPSS seri 24.

\section{HASIL DAN PEMBAHASAN}

Tujuan dari penelitian ini yaitu pertama, untuk mengetahui pengaruh model pembelajaran generatifterhadap kemampuan berpikir kritis fisika peserta didik. Kedua, untuk mengetahui pengaruh pengetahuan awal peserta didik terhadap kemampuan berpikir kritis fisika peserta didik. Ketiga, untuk mengetahui interaksi antara model pembelajaran generatif dengan pengetahuan awal peserta didik terhadap kemampuan berpikir kritis fisika.

Tabel 1. Data Hasil Uji Hipotesis

\begin{tabular}{lrrrrrr}
\hline \multicolumn{1}{c}{ Sumber } & Jumlah Kuadrat & Derajat Bebas & Rata-rataKuadrat & $F_{\text {hitung }}$ & $F_{\text {tabel }}$ & Sig \\
\hline Efek Utama & & & & & & \\
Pengetahuan Awal & & & & & & \\
(Baris) & 2692,801 & 1 & 2692,801 & 42,141 & 4,091 & $<0.05$ \\
Pembelajaran(Kolom) & 579,012 & 1 & 579,012 & 9,061 & 4,091 & $<0.05$ \\
Interaksi & 78,707 & 1 & 78,707 & 1,232 & 4,091 & $>0.05$ \\
Kesalahan & 2492,109 & 39 & 63,900 & & & \\
\hline
\end{tabular}

Pada pelaksanaannya, perlakuan yang diberikan pada kelas eksperimen adalah dengan menerapkan model pembelajaran generatif, sedangkan kelas kontrol dengan menerapkan pembelajaran konvensional. Kedua kelas mendapatkan pengajar yang sama yaitu peneliti sendiri, materi ajar yang sama yaitu momentum dan impuls, serta waktu pembelajaran yang sama yaitu tiga kali pertemuan (3 x 45 menit). Sebelum diberikan perlakuan kedua kelas diberikan tes pengetahuan awal untuk menggolongkan peserta didik yang memiliki pengetahuan awal tinggi dan rendah. Setelah diberikan perlakuan kedua kelas diberikan tes kemampuan berpikir kritis untuk melihat perbandingan nilai kedua kelas.

Berdasarkan uji analisis statistik dengan anava dua jalan diperoleh $F_{\text {hitung }}$ untuk hipotesis pertama dan kedua lebih besar daripada $F_{\text {tabel, nilai signifikan yang }}$ diperoleh sebesar 0,005 dan 0,000 lebih kecil dari 0,05 Sedangkan $F_{\text {hitunguntuk }}$ hipotesis ketiga lebih kecil daripada $\mathrm{F}_{\text {tabel, }}$, nilai signifikan yang diperoleh sebesar 0,274 lebih besar dari 0,05 yang nilainya dapat dilihat pada Tabel 1. Hasil ini menyimpulkan bahwa $\mathrm{H}_{0 \mathrm{~A}}$ dan $\mathrm{H}_{0 \mathrm{~B}}$ ditolak artinya ada pengaruh model pembelajaran generatif terhadap kemampuan berpikir kritis fisika peserta didik dan ada pengaruh pengetahuan awal terhadap kemampuan berpikir kritis fisika peserta didik, sedangkan $\mathrm{H}_{0 \mathrm{AB}}$ diterima yang artinya tidak ada interkasi antara model pembelajaran generatif dengan pengetahuan awal terhadap kemampuan berpikir kritis fisika peserta didik.

\section{Pengaruh Model Pembelajaran Terhadap Kemampuan Berpikir Kritis}

Hasil tes kemampuan berpikir kritis kelas eksperimen yang diberi perlakuan menggunakan model pembelajaran generatif memiliki nilai rata-rata 70,2 , sedangkan pada kelas kontrol yang diberi perlakuan menggunakan pembelajaran konvensional memiliki nilai rata-rata yaitu 61,9. Dapat dilihat dari nilai rata-rata kedua kelas memiliki perbedaan yang cukup jauh. Nilai rata-rata untuk kelas eksperimen lebih tinggi dibandingkan dengan nilai rata-rata di kelas kontrol. Hasil tersebut menunjukkan bahwa model pembelajaran generatif lebih efektif 
daripada pembelajaran konvensional, dimana kelas yang menerapkan model pembelajaran generatif menghasilkan peserta didik dengan kemampuan berpikir kritis yang lebih tinggi dibandingkan dengan kelas yang menerapkan pembelajaran konvensional. Hal ini karena model pembelajaran generatif memberikan kesempatan peserta didik untuk aktif dalam membangun teori berdasarkan pengetahuan yang sudah dimilikinya. Hasil nilai rata-rata tes kemampuan berpikir kritis dapat dilihat pada Tabel 2.

Ketika proses pembelajaran berlangsung di kelas eksperimen peserta didik sangat antusias dengan adanya demonstrasi berupa video permasalahan dari peristiwa sehari-hari terkait dengan materi yang ditampilkan. Karena menurut Nandari (2014) apabila peserta didik mampu mengkonstruksi pemahamannya berdasarkan permasalahan dalam kehidupan sehari-hari yang diberikan, maka peserta didik dapat mengembangkan keterampilan berpikir kritisnya. Saat mengerjakan LKPD masing-masing kelompok saling berdiskusi dan mengeluarkan pikiran maupun pendapatnya terhadap pemahamannya melalui masalah yang ditayangkan oleh peneliti sehingga peserta didik aktif dan kreatif dalam menemukan konsep.

Tabel 2. Hasil Rata-rata Nilai Kemampuan Berpikir Kritis

\begin{tabular}{ccccc}
\hline Kelas & N & $\begin{array}{c}\text { Nilai } \\
\text { Tertingg } \\
\text { i }\end{array}$ & $\begin{array}{c}\text { Nilai } \\
\text { Terenda } \\
\mathbf{h}\end{array}$ & $\begin{array}{c}\text { Rata } \\
\text {-rata }\end{array}$ \\
\hline $\begin{array}{cccc}\text { Eksperime } \\
\text { n }\end{array}$ & 2 & 90 & 45 & 70,2 \\
Kontrol & 2 & & & \\
& 2 & 80 & 45 & 61,9 \\
& 1 & & & \\
\hline
\end{tabular}

Peserta didik tidak hanya kompak dalam berdiskusi dengan sesama anggota kelompok tetapi peneliti memberi kesempatan setiap masing-masing kelompok untuk berargumen dan saling menanggapi sesuai dengan pendapatnya masing-masing lalu mempresentasikan hasil diskusi yang telah didapatkan sehingga peserta didik mampu berpikir kritis untuk menyelesaikan permasalahan. Hal ini sejalan dengan pendapat Ismaimuza (2011) yang mengemukakan seorang peserta didik dapat dikatakan berpikir kritis bila peserta didik tersebut mampu menguji pengalamannya, mengevaluasi pengetahuan, ide-ide dan mempertimbangkan argumen sebelum mendapatkan justifikasi.

Proses pembelajaran di kelas kontrol yang menggunakan model pembelajaran konvensional, peserta didik juga dituntut untuk selalu aktif. Pembelajaran konvensional memberikan kesempatan bagi peserta didik untuk diskusi, presentasi, dan tanya jawab. Namun, selama proses pembelajaran tidak semua bahkan sedikit sekali dari peserta didik yang mampu berdiskusi dengan baik dan paham tentang presentasi yang disampaikan. Ketika proses tanya jawab peserta didik terihat pasif dan tidak bersemangat. Hal ini disebabkan sebagian besar peserta didik hanya berfokus pada cara penyelesaian soal yang diberikan bukan pada konsep apa yang akan didiskusikan. Disamping itu, peserta didik tidak dapat berpikir terbuka dalam memahami suatu konsep sehingga pemahaman peserta didik terhadap konseptidak menyeluruh dan mengakibatkan kemampuan berpikir kritiskelas kontrol lebih rendah dibandingkan kelas eksperimen yang menggunakan model pembelajaran generatif.

Hal ini juga dibuktikan dari sebuah penelitian yang dilakukan oleh Uki (2017) yang menyatakan bahwa model pembelajaran generatif berbasis hands-on activity pada materi fluida dinamis mampu mengoptimalkan kemampuan berpikir kritis peserta didik dalam kegiatan pembelajaran, serta penelitian yang terkait adalah penelitian Dewi(2013) menyatakan bahwa 
kemampuan berpikir kritis antara kelompok yang mengikuti pembelajaran dengan model pembelajaran generatif lebih tinggi dibandingkan dengan model pembelajaran konvensional pada mata pelajaran IPA peserta didik kelas V.

\section{Pengaruh Pengetahuan Awal Terhadap Kemampuan Berpikir Kritis}

Peserta didik yang memiliki pengetahuan awal tinggi mendapatkan nilai rata-rata kemampuan berpikir kritis yang lebih tinggi dibandingkan dengan peserta didik yang memiliki pengetahuan awal rendah. Pada kelas eksperimen dengan model pembelajaran generatif peserta didik yang memiliki pengetahuan awal tinggi mendapatkan nilai rata-rata kemampuan berpikir kritis sebesar 79,545, sedangkan peserta didik yang memiliki pengetahuan awal rendah mendapatkan nilai rata-rata kemampuan berpikir kritis sebesar 60,909. Pada kelas kontrol dengan model pembelajaran konvensional peserta didik yang memiliki pengetahuan awal tinggi mendapatkan nilai rata-rata kemampuan berpikir kritis sebesar 69,444, sedangkan peserta didik yang memiliki pengetahuan awal rendah mendapatkan nilai rata-rata sebesar 56,250. Hasil tersebut dapat dilihat pada Tabel 3 berikut ini.

Tabel 3. Rata-rata Nilai Kemampuan Berpikir Kritis pada Kategori Pengetahuan Awal Peserta Didik

\begin{tabular}{ccccc}
\hline \multirow{2}{*}{ Kelas } & $\begin{array}{c}\text { Pengetahuan } \\
\text { Awal }\end{array}$ & N & Rata-rata & N \\
\hline \multirow{2}{*}{ Eksperimen } & Rendah & 11 & 60,909 & \multirow{2}{*}{22} \\
\cline { 2 - 4 } Kontrol & Tinggi & 11 & 79,545 & \\
\cline { 2 - 4 } & Rendah & 12 & 56,250 & \multirow{2}{*}{21} \\
\cline { 2 - 4 } & Tinggi & 9 & 69,444 & \\
\hline
\end{tabular}

Peserta didik yang memiliki jenjang

pengetahuan awal tinggi akan memiliki tingkat kesiapan yang tinggi dalam menerima pelajaran. Peserta didik dalam kelompok ini memiliki keinginan belajar yang kuat serta berani mengutarakan pendapatnya jika mengalami kesulitan dalam pembelajaran, sehingga hasil prestasi belajarnya tinggi. Peserta didik yang memiliki jenjang pengetahuan awal rendah akan memiliki tingkat kesiapan menerima pelajaran yang rendah pula. Peserta didik yang demikian mempunyai keinginan belajar tidak sekuat peserta didik yang jenjang pengetahuan awalnya tinggi, sehingga dalam pembelajaran bersikap pasif dan hasil belajarnya menjadi rendah (Fatwa, 2018).

Pada penelitian ini peserta didik yang memiliki pengetahuan awal tinggi lebih antusias dan aktif ketika peneliti membantu mengaitkan informasi yang sudah tersimpan di dalam pikiran mereka dengan konsep yang baru dipelajari berupa kejadian atau peristiwa yang sering mereka alami. Sebaliknya peserta didik yang memiliki pengetahuan awal rendah lebih pasif karena mereka kurang memahami keterkaitan antara konsep yang dipelajari dengan kejadian sehari-hari yang tidak pernah dialami atau dibayangkan. Pengetahuan awal peserta didik adalah sejumlah informasi yang dimiliki oleh peserta didik yang berkaitan dengan materi yang akan dipelajari, yang dapat membantunya dalam memahami materi tersebut lebih lanjut. Hal ini sesuai dengan pendapat Muammar et. al. (2015) yang menyatakan bahwa mereka yang memiliki pengetahuan awal tinggi lebih mudah menyesuaikan diri dalam pembelajaran, lebih aktif dan antusias. Dari pemaparan yang telah dijelaskan dapat disimpulkan bahwa kemampuan berpikir kritis fisika peserta didik dengan pengetahuan awal tinggi lebih baik dibandingkan dengan pengetahuan awal rendah.

Hal ini didukung dari sebuah penelitian yang dilakukan oleh Muammar (2015) yang manyatakan bahwa peserta didik dengan pengetahuan awal tinggi memiliki hasil belajar yang lebih baik dari 
pengetahuan awal rendah. Sejalan juga dengan penelitian yang dilakukan oleh Ismaimuza (2011) yang menyatakan kemampuan berpikir kritis matematis peserta didik yang memperoleh pembelajaran berbasis masalah dengan strategi konflik kognitif dengan pengetahuan awal yang tinggi lebih baik daripada pembelajaran konvensional dengan pengetahuan awal yang rendah.

\section{Interaksi Model Pembelajaran Generatif dengan Pengetahuan Awal Terhadap Kemampuan Berpikir Kritis}

Hasil penelitian menunjukkan bahwa variabel bebas yakni model pembelajaran generatif memberikan dampak tersendiri terhadap kemampuan berpikir kritis. Hal ini dapat dilihat dari peningkatan nilai rata-rata kemampuan berpikir kritis kelas eksperimen yang lebih tinggi dari kelas kontrol. Hasil penelitian juga menunjukkan bahwa variabel moderator yakni pengetahuan awal peserta didik memberikan dampak tersendiri terhadap kemampuan berpikir kritis. Hal ini dapat dilihat dari kemampuan berpikir kritis peserta didik yang memiliki pengetahuan awal tinggi, memperoleh nilai rata-rata yang lebih baik dibanding peserta didik dengan pengetahuan awal rendah baik pada model pembelajaran generatif maupun pada model pembelajaran konvensional.

Tidak ada interaksi antara model pembelajaran generatif dengan pengetahuan awal dapat dilihat pada Gambar 1, gambar grafik tersebutmenunjukkan interaksi antara model pembelajaran generatif dengan pengetahuan awal. Berdasarkan Gambar 1kedua garis tidak saling berpotongan melainkan sejajar sehingga tidak ada interaksi antara model pembelajaran generatif dengan pengetahuan awal. Interaksi mangacu pada variabel bebas, variabel moderator dan variabel terikat. Cardinal (2004) mengemukakan bahwa secara statistik suatu variabel dikatakan berinteraksi dengan variabel lainnya jika keduanya memiliki titik pertemuan.

Gambar 1 menunjukkan interaksi antara model pembelajaran dengan pengetahuan awal terhadap kemampuan berpikir kritis. Pada sumbu horizontal terdapat variabel pembelajaran yaitu model pembelajaran generatif dan pembelajaran konvensional, sedangkan pada sumbu vertikal terdapat variabel pengetahuan awal yakni pengetahuan awal tinggi dan rendah. Garis hubungan interaksi pada kedua variabel tidak mengalami perpotongan di satu titik melainkan terpisah satu sama lain, sehingga tidak ada interaksi antara model pembelajaran generatif dengan pengetahuan awal terhadap kemampuan berpikir kritis fisika peserta didik kelas X. Artinya baik model pembelajaran generatif maupun pembelajaran konvensional tidak berhubungan langsung dengan pengetahuan awal, kecuali dengan meningkatkan proses model pembelajarannya menjadi lebih baik dan dilakukan secara konsisten.

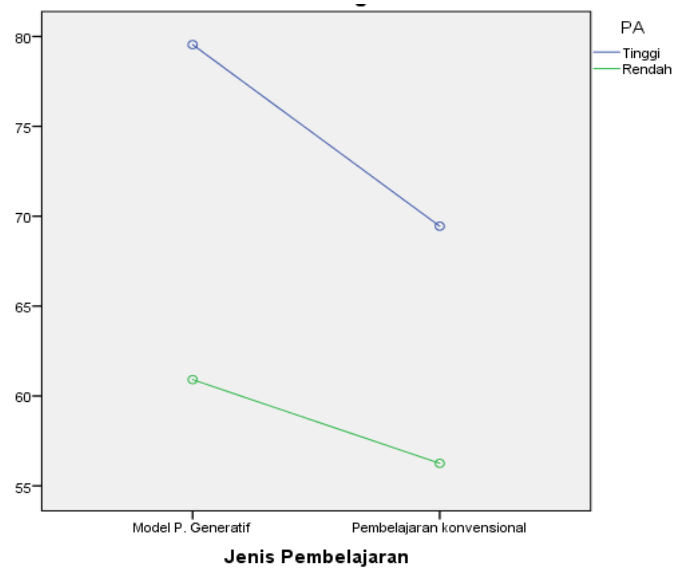

Gambar 1. Interaksi antara Model Pembelajaran Generatif dengan Pengetahuan Awal

Titik temu akan muncul jika salah satu kelas peserta didik yang memiliki pengetahuan awal rendah mampu mencapai kemampuan berpikir kritis yang lebih tinggi dari mereka yang memiliki pengetahuan awal tinggi pada kelas yang sama. Namun pada kenyataannyabahwa pengaruh yang diberikan model pembelajaran terhadap 
kemampuan berpikir kritis merupakan pengaruh yang berdiri sendiri dan tidak berhubungan dengan pengetahuan awal, begitupun sebaliknya pengaruh yang diberikan pengetahuan awal terhadap kemampuan berpikir kritis adalah pengaruh yang berdiri sendiri dan tidak berhubungan dengan model pembelajaran. Dapat disimpulkan bahwa pada pembelajaran fisika dengan menggunakan model pembelajaran apapun, semakin tinggi pengetahuan awal peserta didik maka akan semakin tinggi pula hasil belajarnya. Kecuali dengan meningkatkan proses model pembelajarannya menjadi lebih baik yaitu dengan menambahkan berbagai metode seperti eksperimen, demonstrasi ataupun menggunakan media yang dapat melengkapi kekurangan dari model yang digunakan sehingga dapat memaksimalkan serta diberi perlakuan secara konsisten.

Hasil penelitian ini sejalan dengan temuan penelitian sebelumnya yang dilakukan oleh Muammar et al. (2015) dan Jannah et al. (2015) yang menyimpulkan bahwa tidak ada interaksi antara model pembelajaran dengan pengetahuan awal peserta didik.

\section{PENUTUP}

Pada taraf signifikan 5\%, berdasarkan data yang diperoleh dan hasil dari analisis data yang telah dikemukakan dapat disimpulkan bahwa model pembelajaran generatif dan pengetahuan awal peserta didik berpengaruh positif terhadap kemampuan berpikir kritis fisika peserta didik. Akan tetapi, antara model pembelajran generatif dengan pengetahuan awal tidak memiliki interaksi satu sama lain dalam meningkatkan kemampuan berpikir kritis fisika peserta didik kelas X SMAN 1 Gunungsari.
Adodo, S. O. 2013. Effect if Mind-Mapping as a Self-Regulated Learning Strategy on Students' Achievement in Basic Science And Technology. Mediterranean Journal of Social Sciences. 6(1): 163-172.

BSNP. 2006. Peraturan Menteri Pendidikan Nasional No.23 Tahun 2006 tentang Standar Kompetensi Lulusan untuk Satuan Pendidikan Dasar dan Menengah. Jakarta: Asa Mandiri.

Cardinal, R N. 2004. Anova In Practice And Complex Anova Designs. United States of America: Thompson Learning.

Dewi, K. A. P., Sulastri, M., \& Agustiana, I. G. T. 2013. Pengaruh Model Pembelajaran Generatif Terhadap Kemampuan Berpikir Kritis IPA Siswa Kelas V Di Gugus VIII Kecamatan Buleleng. MIMBAR PGSD Undiksha, 1(1)

Ennis R.H. 2011. The Nature of Critical Thinking: An Outline of Critical Thingking Dispositions and Abilities. University of Illinois. On line at http://faculty.education.illinois.edu/r hennis/documents/tłTheNatureofCrit icalThinking 51711_000.pdf

[diakses tanggal 29 November 2018]

Fatwa, M. W., Harjono, A., \& Jamaluddin, J. 2018. Pengaruh Model Pembelajaran Inkuiri Terbimbing Terhadap Keterampilan Proses Dan Penguasaan Konsep Sains Ditinjau Dari Pengetahuan Awal Peserta Didik. Jurnal Pendidikan Fisika dan Teknologi, 4(1), 121-130.

Gunawan, G., \& Liliasari, L. 2012. Model Virtual Laboratory Fisika Modern Untuk Meningkatkan Disposisi Berpikir Kritis Calon Guru. Jurnal Cakrawala Pendidikan, 5(2): 185199.

Gunawan, G., Harjono, A., \& Sutrio, S.2017. Multimedia Interaktif dalam Pembelajaran Konsep Listrik bagi

\section{REFERENSI}


Calon Guru. Jurnal Pendidikan Fisika dan Teknologi, 1(1), 9-14.

Hakim, A. R. 2015. Pengaruh model pembelajaran generatif terhadap kemampuan pemecahan masalah matematika. Formatif: Jurnal Ilmiah Pendidikan MIPA, 4(3).

Handriani, L. S., Harjono, A., \& Doyan, A. 2017. Pengaruh Model Pembelajaran Inkuiri Terstruktur dengan Pendekatan Saintifik Terhadap Kemampuan Berpikir Kritis dan Hasil Belajar Fisika Siswa. Jurnal Pendidikan Fisika dan Teknologi, 1(3), 210-220.

Hikmawati \& Gunada, IW. 2013. Kajian Fisika SMA. Mataram:FKIP Press Universitas Mataram.

Ismaimuza, D.2017. Kemampuan berpikir kritis matematis ditinjau dari pengetahuan awal siswa. Jurnal Pendidikan Matematika, 2(1).

Jannah, S. N., Doyan, A., \& Harjono, A. 2017. Pengaruh Model Pembelajaran Kooperatif dengan Pendekatan Problem Posing Ditinjau Dari Pengetahuan Awal Terhadap Kemampuan Pemecahan Masalah Fisika Siswa SMK. Jurnal Pendidikan Fisika dan Teknologi, 1(4), 257-264.

Johnson, E.B. 2008. Contextual Teaching and Learning: Menjadikan Kegiatan Belajar-Mengajar Mengasyikkan dan Bermakna. Diterjemahkan Oleh Ibnu Setiawan. Bandung: Penerbit MLC.

Muammar, H., Harjono, A., \& Gunawan, G. 2017. Pengaruh Model Pembelajaran Assure dan Pengetahuan Awal Terhadap Hasil Belajar IPA-Fisika Siswa Kelas Viii SMPN 22 Mataram. Jurnal Pendidikan Fisika dan Teknologi, 1(3), 166-172.

Nandari, E. M. 2014. Pengaruh Model Pembelajaran Generatif terhadap Keterampilan Berpikir Kritis Fisika Siswa Kelas X di SMA Negeri 7
Malang. SKRIPSI Jurusan FisikaFakultas MIPA UM.

Putri, G.A.A.A., Putra, DB.K.N.S., dan Suardika, I.W.R. 2014. Pengaruh Penerapan Model Pembelajaran Generatif Berbasis Bekerja Ilmiah Terhadap Hasil Belajar IPA Siswa Kelas V SD Gugus Mayor Metra Denpasar Utara Tahun Ajaran 2013/2014. E-journal MIMBAR PGSD Universitas Pendidikan Ganesha Jurusan PGSD. 2 (1): 1-10.

Romadlonah, S. 2013. Pengembangan Pembelajaran Generatif Berbasis Konteks untuk Meningkatkan Kompetensi Komunikasi Lisan Siswa Kelas VIII SMPN 1 Batangan. Piwulang Jawi: Javanese Learning and Teaching Journal.2 (1): 1-5.

Saavedra, A. R. and Opfer, V. D. 2012. Teaching and Learning $21^{\text {st }}$ Century Skills. Global Cities Education Network Report (Asia Society). Page 4.

Shoimin, A. 2014. 68 Model Pembelajaran Inovatif dalam Kurikulum 2013. Yogyakarta: Ar-Ruzz Media.

Sugiana, I. N., Harjono, A., Sahidu, H. \& Gunawan. 2016. Pengaruh Model Pembelajaran Generatif Berbantuan Media Laboratorium Virtual Terhadap Penguasaan Konsep Fisika Siswa pada Materi Momentum dan Impuls. Jurnal Pendidikan Fisika dan Teknologi 2(2). 1-5.

Uki, R. S., Saehana, S., \& Pasaribu, M. 2017. Pengaruh Model Pembelajaran Generatif Berbasis Hands-on activity pada Materi Fluida Dinamis terhadap Kemampuan Berpikir Kritis Siswa. Physics Communication, 1(2), 6-11.

Wena, M. 2014. Strategi Pembelajaran Inovatif Kontemporer. Jakarta: Bumi Aksara. 